\section{Conditions of Sediment Transport of Styr Basin Rivers}

Received 2016/01

Accepted after revision 2016/04

\title{
Conditions of Sediment Transport of Styr Basin Rivers
}

\section{Olexandr Obodovskyi, Kostiantyn Danko}

Geography Department, Taras Shevchenko National University of Kyiv, Kyiv, Ukraine

Corresponding author: obodovskiy58@gmail.com

O. Obodovskyi, Geography Department of the Taras Shevchenko National University of Kyiv

St. Volodymyrska 64/13, Kyiv-01103, Ukraine

The paper presents the results of studies of the conditions of sediment transport of Styr basin rivers, tributaries of the right bank of Pripyat, which were held on 9 rivers of the basin and 2 streams of the Styr River (Stara Styr and Prostyr). According to 30 representative cross-sections of the studied rivers, the hydraulic parameters of channels are measured and channel alluvium is sampled to determine its coarseness. The average flow rates under the bankfull stage are set for the mentioned areas and non-eroding and eroding velocities of the stream flow are calculated. It is determined that the passage of bankfull stages in edges complies with the conditions of dynamic equilibrium of the erosion-accumulative processes. The ratios of average flow velocities under the bankfull stage with non-eroding and eroding velocities enable determining the orientation of channel deformations in the areas of the rivers. A new approach to the determination of non-eroding velocities for unexplored areas of the rivers is represented, which is based on the dependence of non-eroding and average flow velocities at the bankfull stage. It is shown that an increase in slopes and velocities of the stream of the Styr River cause the activation of channel processes down the river.

Keywords: Styr basin; non-eroding velocity; eroding velocity; bankfull stage; erosion- accumulative processes.

\section{Introduction}

Solving of the most purposes of stream regulation requires a detailed study of the conditions of sediment transport, their coarseness and erosion stability. It is the sediment transport that serves as a link of active (water flow) and passive (geological and geomorphological structure of the riverbed, floodplain and basin as a whole) factors of channel processes. In this aspect, it is important to take into account the nature of non-eroding velocities $\left(V_{n e}, \mathrm{~m} / \mathrm{s}\right.$ ) (maximum allowable flow velocities at which the channel is not eroded) and eroding velocities $\left(V_{e}, \mathrm{~m} / \mathrm{s}\right)$ (the velocities at which the disruption of sediments and active sediment transport 
occur). These characteristics reflect the conditions for the sediment transport and the ability of the stream to perform the eroding function in relation to the channel soils. Properties of the channel processes in many moments depend on the value of the said characteristics, which are determined by the value of the diameter of bed sediments $\left(d_{50 \%}, \mathrm{~mm}\right)$ to some extent.

The demand of the mentioned aspects in the study of channel-formation especially increases in the rivers of the Polesie area of Ukraine and the Republic of Belarus (Figure 1), where they occur in the conditions of free development of channel deformations (Obodovskyi, 2001).
A typical example of such rivers is the stream flows of the transboundary basin of Styr, for which the conditions of sediment transport are actualised also by significant economic development. A survey of sediment transport were conducted for this river along the whole length and its tributaries, based on a river basin approach.

The purpose of the study is to identify non-eroding and eroding velocities of the streams of the Styr River basin under channel-forming water discharge at the bankfull stage (channel-forming water level) (Stream, 2009) and to establish the conditions of dynamic balance of erosion-accumulation processes in these watercourses.

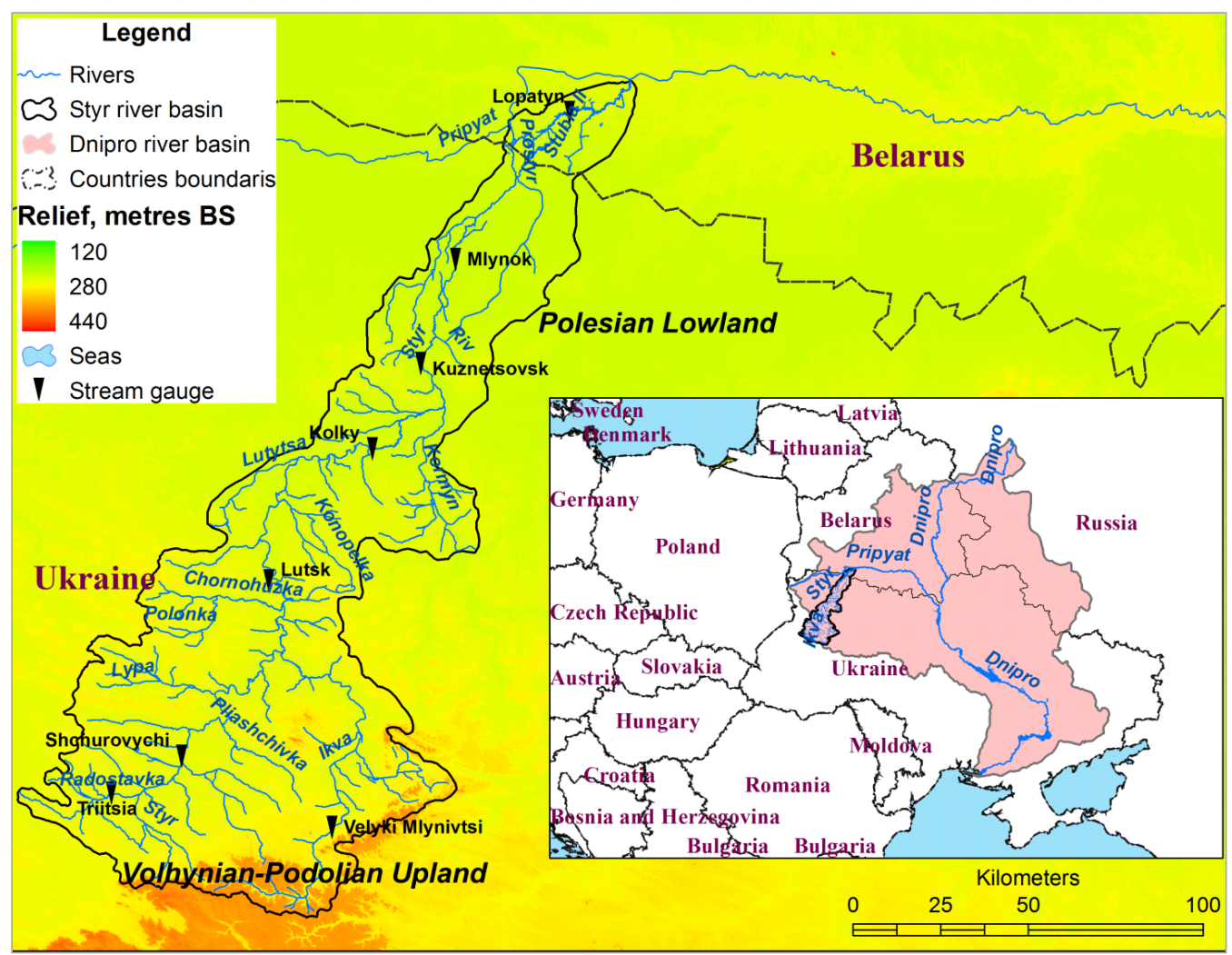

Fig. 1

Basin of the Styr River

\section{Materials and methods}

Assessment of sediment transport is one of the most difficult areas of the study of channel processes. In practice, such an assessment involves defining the transport capacity of the flow. Its appropriate average turbidity of the flow (Makkaveev and Chalov, 1986) is taken as an indicator of the transporting capacity. But the most indicative and representative figures in this context may be non-eroding and eroding velocities of the flow, as they reflect the conditions of the beginning of the breakdown of particles of channel alluvium and its whole transportation. 
Today, in the area of river hydraulics a number of studies are implemented for assessment of channel-formation processes. Among the authors of such developments one should note G. I. Shamov (1959), S. Lelyavskiy (1955, 1961), A. V. Karaushev (1977), I. F. Karasyev (1965), N. I. Makkaveev, R. S. Chalov (1986), V. N. Goncharov (1962), I. I. Levi (1957), O. G. Obodovskyi (2001), V. V. Onischuk (1975), V. P. Rogunovich (1989), V. N. Korneev (2010), as well as Ts. E. Mirtshulava (1988). The latter has set (now classic) the relationship (1) between the ratio of eroding and non-eroding velocities

$$
V_{e}=1.4 V_{n e}
$$

where $V_{e}$ is eroding velocity, $\mathrm{m} / \mathrm{s} ; V_{n e}$ - non-eroding velocity, $\mathrm{m} / \mathrm{s}$.

It should be noted that the mass movement of sediments begins when the flow reaches eroding velocity. The definition of non-eroding velocities may be carried out by the analysis of reference tables designed for natural open channels composed of loose soils or on a number of empirical formulas (Popov, 1958; Bolshakov, 1977). In such a case, one should take into account the coarseness of the bottom sediments and the average depth of the flow.

\section{Results and discussion}

For determination of the non-eroding velocities of the flow of the Styr basin rivers and for determination of the conditions of dynamic balance of erosion-accumulative processes of the rivers, the field studies were carried out on 9 rivers of the basin and two streams of the Styr River (Stara Styr and Prostyr). According to 30 cross-sections (17 cross-sections on the Styr River before the branching into Stara Styr and Prostyr), the hydraulic parameters of the channels were measured and channel alluvium was sampled for determination of its coarseness (Figure 2). Given that the activation of channel-formation processes is observed in the conditions of flow passing within the channel edges, as evidenced by maximum Chezy's velocity factors at the bankfull stage (Danko and Obodovskyi, 2014), non-eroding $\left(V_{\text {ne(bf) }}\right)$ and eroding $\left(V_{e(b f)}\right)$ velocities of the flow of the rivers within the studied cross-sections were designed precisely for such conditions (Table 1).
Fig. 2

Chart of location of the studied cross-sections in Styr basin.

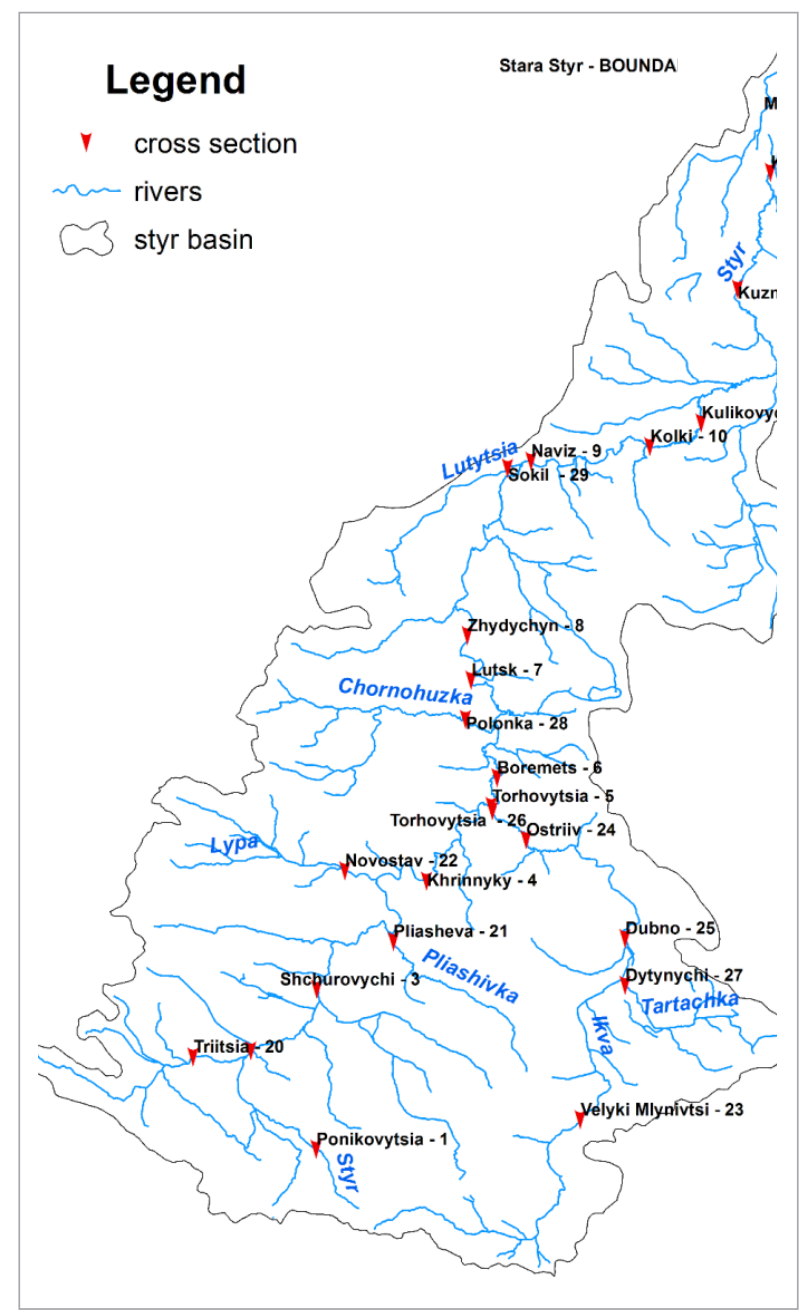

In Table 1, $V_{m(b)}$ reflects the average velocity of the flow at the channel bankfull stage, calculated by Chezy's equation

$$
V_{m(b f)}=C \sqrt{R I}
$$

where $V_{m(b f)}$ is the average flow velocity at the bankfull stage, $\mathrm{m} / \mathrm{s} ; C$ - Chezy's factor, which depends on the roughness of the channel, $\mathrm{m}^{0,5} / \mathrm{s} ; R$ - hydraulic radius of the channel (at the bankfull stage), $m$ (for lowland rivers $R \approx h$ ( $h$ - the average depth of the channel, $\mathrm{m}$ ); $I$ - the slope of the water surface (natural), $\mathrm{m} / \mathrm{m}$.

Non-eroding velocities were determined by analysis of the coarseness of bottom sediments and the average 
depth at the bankfull stage (Williams, 1978; Rosgen, 2004; Bent and Waite, 2013) by the reference tables (Popov, 1958; Bolshakov, 1977; Simons and Sentürk, 1977). Eroding velocities were determined by the calculations based on equation (1).

The obtained results (Table 1) demonstrate that at the bankfull stage the flow (represented by characteristic $\left.V_{m(b f)}\right)$ is in a dynamic balance of erosion-accumulative processes. It is indicatively illustrated by the charts of the dynamics of the average, non-eroding and eroding velocities of the flow, plotted for the Styr River (Figure

\section{Table 1}

Calculated velocities of Styr basin rivers with a diameter of bottom sediment $d_{50 \%}$

\begin{tabular}{|c|c|c|c|c|c|}
\hline № & River - Cross-section & $\begin{array}{c}\mathrm{d} 50 \%, \\
\mathrm{~mm}\end{array}$ & $\begin{array}{c}V m(b f), \\
m / s\end{array}$ & $\begin{array}{c}\text { Vne(bf) } \\
\mathrm{m} / \mathrm{s}\end{array}$ & $\begin{array}{c}\mathrm{Ve}(\mathrm{bf}), \\
\mathrm{m} / \mathrm{s}\end{array}$ \\
\hline 1 & 2 & 3 & 4 & 5 & 6 \\
\hline 1 & Styr - Ponikovytsia & 0.17 & 0.47 & 0.33 & 0.47 \\
\hline 2 & Styr - Stanislavchik & 0.38 & 0.40 & 0.51 & 0.72 \\
\hline 3 & Styr - Shchurovychi & 0.29 & 0.66 & 0.50 & 0.70 \\
\hline 4 & Styr - Khrinnyky & 0.25 & 0.65 & 0.58 & 0.82 \\
\hline 5 & Styr - Torhovytsia & 0.12 & 0.51 & 0.47 & 0.66 \\
\hline 6 & Styr - Boremets & 0.11 & 0.54 & 0.47 & 0.66 \\
\hline 7 & Styr - Lutsk & 0.13 & 0.45 & 0.47 & 0.66 \\
\hline 8 & Styr - Zhydychyn & 0.12 & 0.69 & 0.55 & 0.76 \\
\hline 9 & Styr - Naviz & 0.39 & 0.56 & 0.62 & 0.87 \\
\hline 10 & Styr - Kolki & 0.17 & 0.81 & 0.57 & 0.80 \\
\hline 11 & Styr - Kulikovychi & 0.39 & 0.57 & 0.60 & 0.85 \\
\hline 12 & Styr - Kuznetsovsk & 0.50 & 0.63 & 0.58 & 0.81 \\
\hline 13 & Styr - Krymne & 0.14 & 0.80 & 0.46 & 0.64 \\
\hline 14 & Styr - Mlynok & 0.48 & 0.77 & 0.60 & 0.84 \\
\hline 15 & Styr - Konyk & 0.39 & 0.73 & 0.57 & 0.79 \\
\hline 16 & Styr - Zarichne (left arm) & 0.30 & 0.57 & 0.48 & 0.68 \\
\hline 17 & Styr - Zarichne (right arm) & 0.25 & 0.61 & 0.49 & 0.68 \\
\hline 18 & Stara Styr - BOUNDARY UA-BY & 0.88 & 0.34 & 0.60 & 0.83 \\
\hline 19 & Prostyr - BOUNDARY UA-BY & 0.49 & 0.41 & 0.50 & 0.70 \\
\hline 20 & Radostavka - Triitsia & 0.34 & 0.57 & 0.48 & 0.67 \\
\hline 21 & Pliashivka - Pliasheva & 0.25 & 0.54 & 0.46 & 0.64 \\
\hline 22 & Lypa - Novostav & 0.14 & 0.65 & 0.46 & 0.64 \\
\hline 23 & Ikva - Velyki Mlynivtsi & 0.34 & 0.87 & 0.50 & 0.70 \\
\hline 24 & Ikva - Dubno & 0.39 & 0.87 & 0.51 & 0.72 \\
\hline 25 & Ikva - Ostriiv & 0.17 & 0.93 & 0.62 & 0.87 \\
\hline 26 & Ikva - Torhovytsia & 0.25 & 0.47 & 0.55 & 0.76 \\
\hline 27 & Tartachka - Dytynychi & 0.37 & 0.84 & 0.48 & 0.67 \\
\hline 28 & Chornohuzka - Polonka & 0.22 & 0.69 & 0.44 & 0.62 \\
\hline 29 & Lutytsia - Sokil & 0.096 & 0.26 & 0.22 & 0.30 \\
\hline 30 & Stubla - Sernyky & 0.36 & 0.87 & 0.48 & 0.67 \\
\hline
\end{tabular}

3). In Figure 3, the trend of the average bankfull velocities (middle line - solid) (Vm(bf)) is clearly distinguished between the lines of the trend of non-eroding (the bottom line - dotted) (Vne(bf)) and eroding velocities (top line - dashed) $(\mathrm{Ve}(\mathrm{bf}))$ of the flow in the same conditions. Thus, in the course of passage of channel-forming water discharges in channel edges (at the bankfull stage) - Qbf, m3/s, the movements of bottom channel sediments appear. It is the discharge, at which the channel deformations begin to emerge, which have the reversible erosion-accumulative nature.

Thus, the state of dynamic balance of erosion-accumulation processes corresponds to the ratio of average velocities at the bankfull stage and non-eroding velocities equal to 1.2-1.3 $\left(V_{m(b f)} / V_{\text {ne(bf) }}=1.2-1.3\right)$. Such a distribution as a whole meets the provisions of the conditions of $d y-$ namic balance in the "flow-channel" system (Onischuk, 2006), (Obodovskyi et al, 2010), where the number of sediments transported from the river section is conditionally compensated by sediments transported from the upper section.

As for the dynamics of the coarseness of bottom sediments of the Styr River along the length of its bed, it is found that the size of average fractions of bottom sediments gradually grows in the direction from the source to the mouth (Figure 4).

The obtained results allow looking to the postulate by H. Sternberg (1875) about abrasion of the sediments along the river from a different perspective. Sternberg's law comes from the fact that the coefficient of abrasion of the particle is proportional to its velocity. To that end, one can expect decreasing the diameter of the particles of bottom sediments throughout the flow of the river not only due to abrasion of the particles, but also decreasing gradient of the flow throughout the length (Karaushev, 1977). At the same time, the results of the study of spatial measurements of bottom sediments of the Styr River argue the opposite (Figure 4).

The revealed feature is explained by the similar tendency of growth of the average flow velocities along the river, which is associated with the channel morphology and increased hydraulic gradient downstream (Figures $5,6)$. This is favoured by the longitudinal profile of the Styr River, which has a slightly convex shape (Figure 6), which determines the increase in the slope in the down- 
Fig. 3

Distribution of mean velocities,

non-eroding

velocities and eroding velocities

at the bankfull stage along the Styr River at the section

Ponykovytsia boundary UA-BY (branch Prostyr).

Fig. 4

Tendencies of change of the average diameter of channel bottom sediments and average velocities of the flow of the Styr River at the bankfull stage downstream.
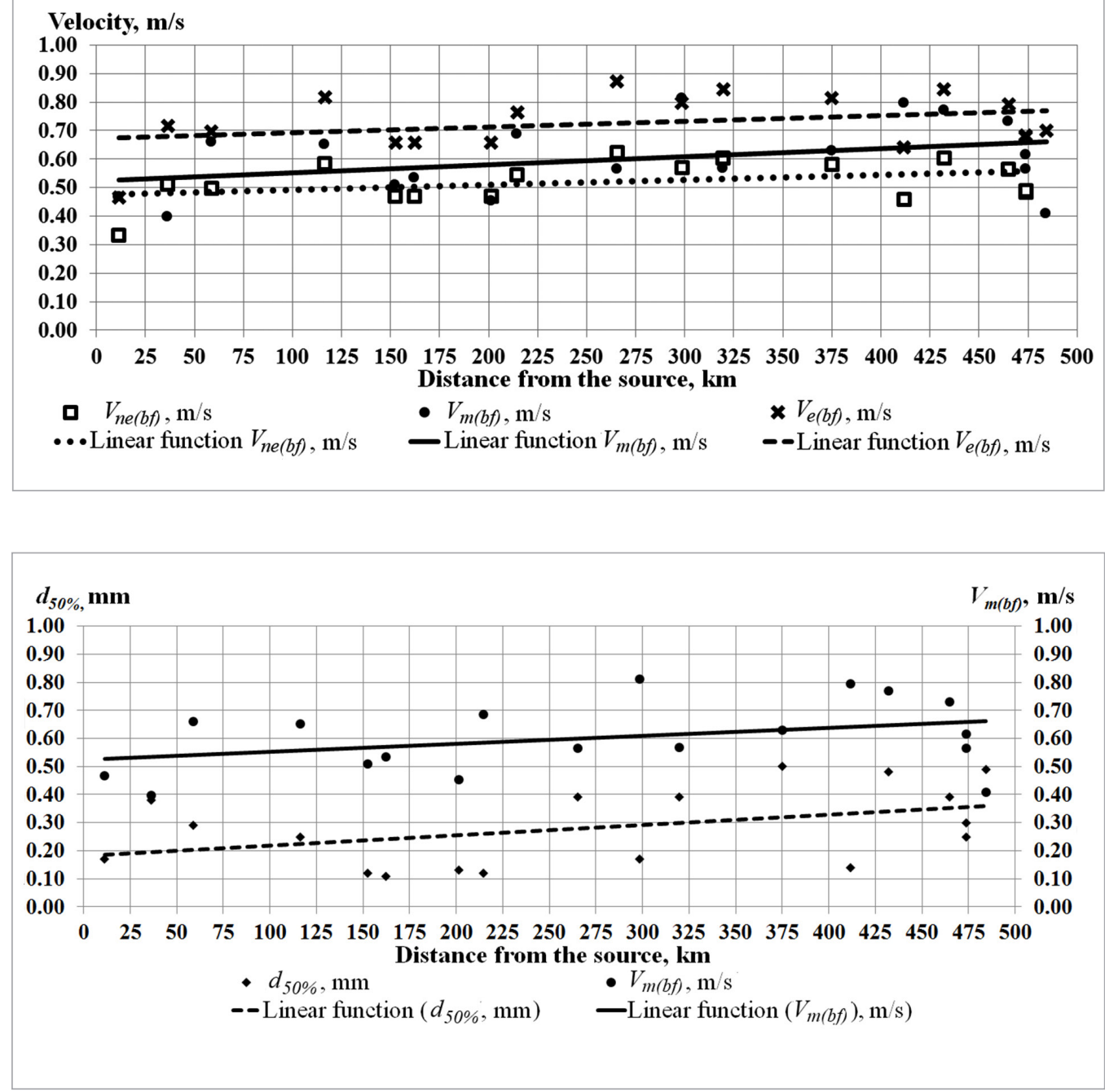

Fig. 5

Tendency of change of the average diameter of channel bottom sediments and hydraulic slopes of the Styr River at the bankfull stage downstream.

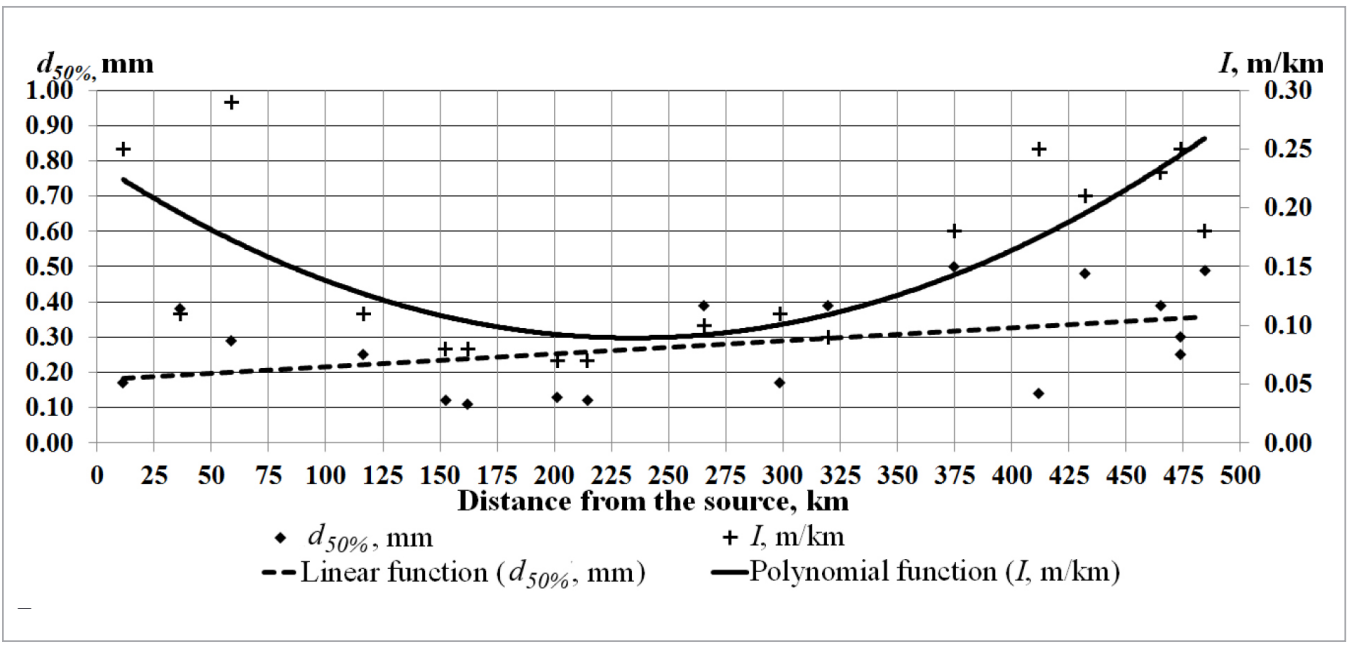




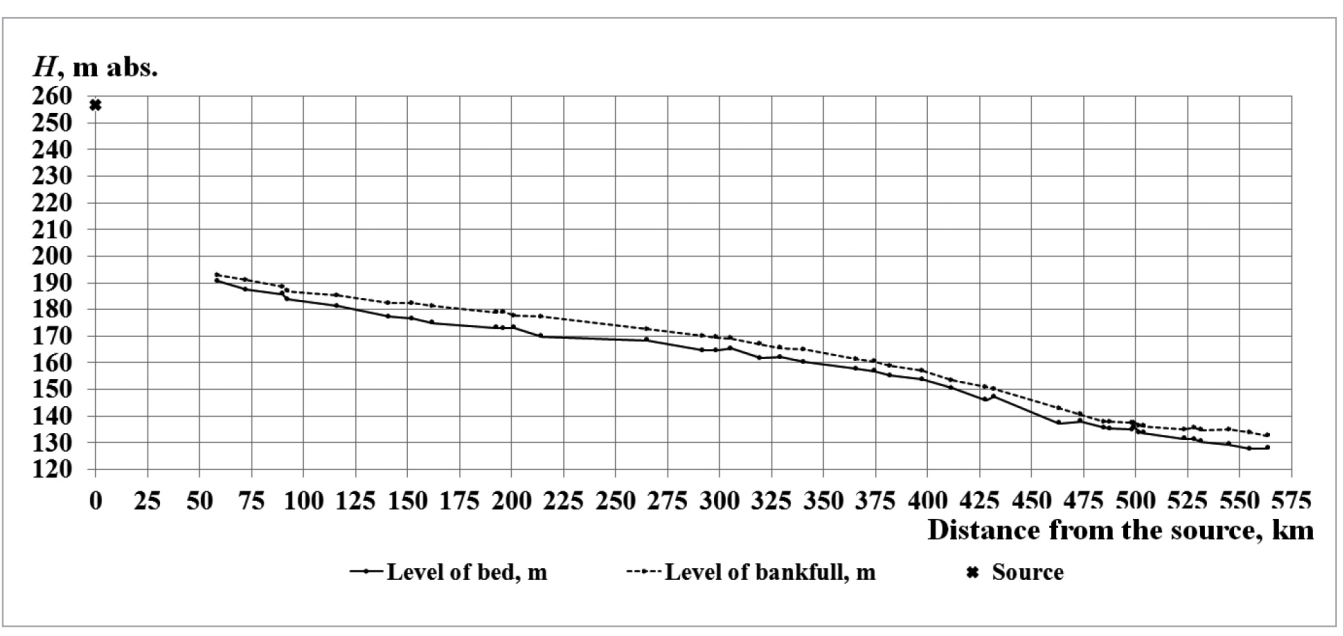

Fig. 6

Longitudinal profile of Styr river on Shchurovychi section (UA) Goltsy (BY). stream, and as a consequence, an increase in the flow velocity. As a result, the upward trend of growth of the average diameter of bottom sediment down the length of the river is likely due to the fact that smaller fractions of bed sediment are simply washed out, transit into the suspension state and are carried by the flow to the lower parts of the river.

The trend of growth of the coarseness of bottom sediments can be justified by such an analysis of inequality $V_{n e(b f)}<V_{m(b f)}<V_{e(b f)}$, which determines the balance, dynamic balance of erosion-accumulation processes and enables determining the direction of channel processes on a particular section of the river.

Analysis of the ratio of the calculated velocities of the flow at the bankfull stage (Table 1) reveals that only in 4 of 17 sections ((No. of cross-sections in Table 1, Figures $2: 2,7,9,11)$ mentioned inequality is violated in favour of $\left(V_{m(b f)} \leq V_{\text {ne(bf })}\right)$, which suggests that in these sections the average velocities of the flow are below the non-eroding velocities. Such conditions indicate the development of processes of sediment accumulation and low transport capacity of the flow. In sections (No. of cross-sections in Table 1, Figure 2: 1, 10, 13), there are erosion processes in the stream channel, since within their boundaries the average velocities at the bankfull stage are equal to or exceed the eroding velocities $\left(V_{e(b f)} \leq V_{m(b f)}\right)$. In all other sections (almost throughout the length of the river) of Styr, the inequality $V_{n e(b f)}<V_{m(b f)}<V_{e(b f)}$ is preserved (No. of cross-sections in Table 1, Figure 2: 3-6, 8, 12, 14-17), i.e. the balance of sediments is preserved.
In turn, in sections (No. of cross-sections in Table 1, Figure 2: 18, 19) which are located in the arms of the Styr River (Stara Styr and Prostyr) below the bifurcation of the river near Zarichne area (479 km from the source), the inequality of dynamic balance of erosion-accumulation processes is $\left(V_{m(b f)} \leq V_{\text {ne(bf) }}\right)$. This indicates the manifestation of the accumulation of the lower flow of the river and supports the conclusion that small bottom sediments washed out in the upstream are re-deposited in the downstream.

Based on the assessment of the ratios of calculated flow velocity characteristics, the direction of channel processes was also evaluated in other rivers of the studied basin (Table 1). Thus, the manifested signs of growing accumulation of sediments as a consequence of the predominance of inequality $\left(V_{m(b f)} \leq V_{n e(b f)}\right)$ are observed in section No. 26 (Table 1, Figure 2), wherein the average flow velocity is much lower than the non-eroding velocity. In sections (No. of cross-sections in Table 1, Figure 2: 22-25, 27, 28, 30), the erosion processes appear, since the average velocities at the bankfull stage exceed the eroding velocities $\left(V_{e(b f)} \leq V_{m(b f)}\right)$, or are proximal thereto. The results of the evaluation of channel deformation orientation obtained in this way, as a whole coincide with the results of the evaluation of the channel stability by index of K.V.Grishanin (Danko, 2014).

The foregoing results of the evaluation of the conditions of sediment transport and the development of channel processes on the Styr River (quasi-continuous) as well as its tributaries and the arms (discretely) enable gener- 
ating the relationship between the non-eroding velocities and the average velocity of the flow at the bankfull stage $V_{\text {ne(bf) }}=f\left(V_{m(b f)}\right)$ (Figure 7). The obtained dependence allows determining the non-eroding velocities through formula (1), and eroding velocities of the flow for sections with a lack of information about the coarseness of alluvium for the rivers of the mentioned basin. These dependences should be built for each major river individually (for the Styr River (Figure 7a)), or a group of the rivers of the same order (tributaries of Styr (Figure 7b)). This principle clarifies the procedure for calculating the non-eroding and eroding velocities of unexplored areas to much extent, thus expanding the scope of the evaluation of sediment transport in the absence of data about them.

\section{Conclusions}

According to the data of the field studied in 30 sections of the rivers of Styr basin, the non-eroding and eroding velocities of the flow are calculated. The passage of channel-forming water discharges in edges (at the bankfull stage) was found to correspond to the conditions of dynamic balance of erosion-accumulative processes. Dynamic balance corresponds to the moment when the average flow velocities at the bankfull stage exceed the non-eroding velocities by 1.2-1.3 times. Evaluation of inequality $V_{\text {ne(bf) }}<V_{m(b f)}<V_{e(b)}$ enables determining the conditions of dynamic balance of erosion-accumulation processes and detect the direction of channel process-

Fig. 7

Relation graph $\operatorname{Vne}(\mathrm{bf})=\mathrm{f}(\mathrm{Vm}(\mathrm{bf}))$ -

Styr River (a), tributaries of Styr

(b).
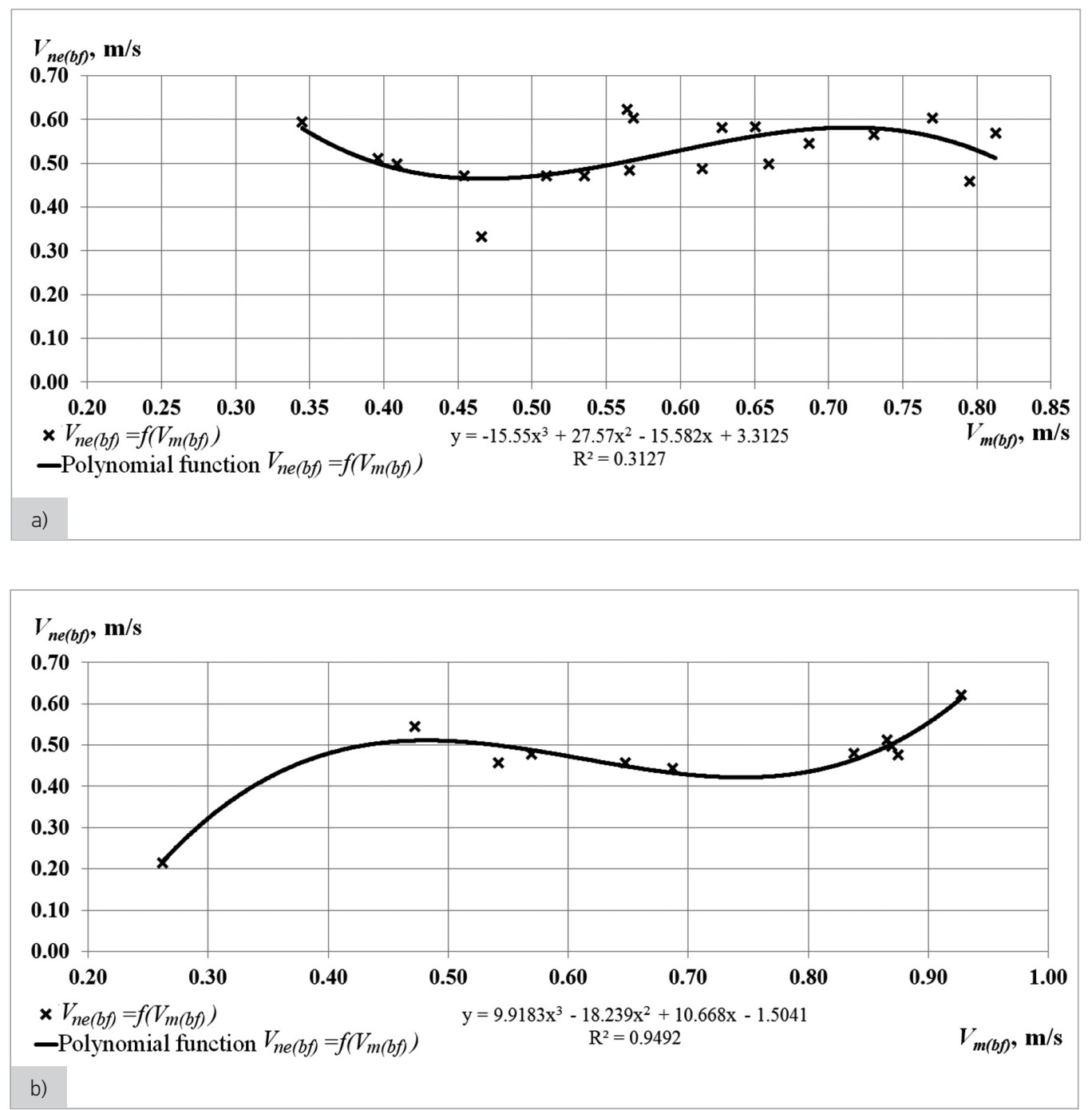
es on a particular section of the river. The processes of accumulation are recorded under the condition that the average flow velocities in the section of the river are below the non-eroding velocities $\left(V_{m(b f)} \leq V_{\text {ne(bf })}\right)$. In a situation when the average velocities exceed the eroding

\section{References}

Bent G. C., Waite A. M. (2013). Equations for Estimating Bankfull Channel Geometry and Discharge for Streams in Massachusetts. Scientific Investigations Report. http://dx.doi. org/10.3133/sir20135155

Bolshakov V. A. (1977). Manual for hydraulics. Kiev. Publishing Association "Vishcha Shkola".

Danko K. Yu. (2014). Types of channels of the Styr river basin, their hydraulic characteristics and stability conditions. Journal of cartography: Collected Works, K.: KNU. Taras Shevchenko National University of Kyiv, Issue 10, 146-178.

Danko K. Yu., Obodovskyi O. G. (2014). Space-time assessment of the channel-forming water discharges in Styr river basin. Geographical Bulletin. Issue 1 (28), 56 - 68.

Goncharov V. N. (1962). Channel flow dynamics. Leningrad. Hydrometeorological publishing house.

Karasev I. F. (1965). Transportation capacity of turbulent flows and deformation of channel in the cohesive soils. Proceedings of GGI. Issue 124, 55-90.

Karaushev A.V. (1977). Theory and methods of calculation of river sediments. Leningrad. Gidrometeoizdat .

Korneev V. N. (2010). Management of water resources of upper Pripyat and Beloozersk Supply System of Dnieper-Bug Canal. Minsk: Knigazbor.

Lelyavskyi S. (1955). Introduction to the river hydraulics (sediment transport and river channel). London.

Levy I. I. (1957). Channel flow dynamics. M.: Gosenergoizdat.

Leopold L. (1994). A View of the River. Harvard University Press, Cambridge, MA.

Makkaveev N. I., Chalov R. S., Channel processes. M.: Publishing House of MSU.

Mirtskhulava Ts. E. (1988) Basics of physics and mechanics of channel erosion. L.: Gidrometeoizdat.

Obodovskyi O. G. Onischuk V. V. Grebin V. V. et al (2010). Channel processes of Limnytsya K: Nicka-Centre. velocities $\left(V_{e(b f)} \leq V_{m(b f)}\right)$, the erosion processes are manifested. Analysis of relationship $V_{\text {ne(bf) }}=f\left(V_{m(b f f}\right)$ makes it possible to establish non-eroding design velocities in areas with missing observations for sediments.

Obodovskyi O. G. (2010). Hydrological-ecological assessment of the channel processes (by example of Ukrainian rivers on). K.: Nika Center.

Onischuk V. V. (2006) The fundamental properties of open dynamical systems in the context of the evolution of channel processes: invariance, ergodicity, meandering. Hydrology, hydroecology and hydrochemistry. Kyiv.

Onischuk V. V., Bilchuk A. S., Kozitskii O. N. (1975). Methods and some results of studies of non-eroding flow velocities for beds composed of non-homogeneous loose soils. Irrigation and Water Management. Issue 35, 83-92.

Popov V. N. (1958). Tables for determining the velocity characteristics, maximum and allowable velocity of water flow in open channels. Sat.: In collection: Improvement of hydraulic calculation of road drainage channels and structures, Issue 2. Kiev Automobile and Road Institute.

Rogunovich V.P. (1989). Automation of mathematical modeling of the movement of water and impurities in the water flow system. L. Gidrometeoizdat.

Rosgen D. (1996). Applied river. Minneapolis, Minnesota: Media Companie.

Shamov G. I. (1959). River sediments. Leningrad. Hydrometeorological publishing house.

Simons D. B. Sentürk F. (1977). Sediment Transport Technology: Water and Sediment Dynamics. Hardcover.

Sternberg, H. (1875) Untersuchungen über Längen- und Querprofil geschiebeführender flüss: Zeitschrift für Bauwesen, v. $25,483-506$.

Stream Geomorphic Assessment Handbooks. Appendix K (2009) Identification of Bankfull Stage Vermont Agency of Natural Resources.

Williams, G. P. (1978). Bankfull discharge of rivers, Water Res. Issue 14 (6), 1141-1154. 


\section{Nuosèdų pernešimo sąlygos Styr baseino upèse}

\section{Olexandr Obodovskyi, Kostiantyn Danko}

Šiame straipsnyje pateikiami nuosèdu pernešimo sąlygu Styr baseino upèse, Pripetės upès dešiniojo kranto intakuose, tyrimų rezultatai, kurie buvo atlikti 9 baseino upėse ir 2 Styr upés šaltiniuose (Stara Styr ir Prostyr). Buvo išmatuota 30 reprezentacinių tiriamujų upių skersinių pjūvių, ir nustatyti kanalų hidrauliniai parametrai bei buvo paimti kanalu samplavų bandiniai, siekiant nustatyti jų šiurkštumą. Tyrimo vietose buvo nustatyti vidutiniai upès tèkmès greičiai esant poplūdžiui ir buvo apskaičiuoti upès tèkmès neeroziniai ir eroziniai greičiai. Buvo nustatyta, kad upės pratekejjimas poplūdžio sąlygomis upes kraštuose atitinka didejjančios erozijos procesų dinaminès pusiausvyros sąlygas. Vidutinių erozinių ir neerozinių upès tèkmès greičių santykiai esant poplūdžiui leidžia nustatyti kanalu deformacijų orientaciją tiriamosiose upių vietose. Straipsnyje pristatomas naujas neištirtų upès vietų neerozinių greičių nustatymo būdas, kuris yra paremtas priklausomybe tarp neerozinių ir vidutinių upès greičių esant poplūdžiui. Parodyta, kad Styr upés nuolydžių ir greičių padidèjimas pasroviui aktyvuoja kanalinius procesus.

Raktiniai žodžiai: Styr baseinas, neerozinis greitis, poplūdžio sq̨lygos, didejjančios erozijos procesai. 